Semarang

State University

Undergraduate

LAWE

SOCIETY

REVIEW

VOLUME 1 ISSUE 2, JULY 2021
ISSN (Print): 2807-8225 ISSN (Online): 2807-8683

History of Article

Submitted: December 2020

Revised: March 2021

Accepted: May 2021

How to cite:

Yusuf, W. A. (2021). Drugs Abuse, Law, and Society: The Role of Penitentiary Institution. Semarang State University Undergraduate Law and Society Review, 1(2), 113-124. https://doi.org/10.15294/lsr.v1i2.50550

(C) 2021 Authors. This work is licensed under a AttributionNonCommercial-ShareAlike 4.0 International (CC BY-NC-SA 4.0). All writings published in this journal are personal views of the authors and do not represent the views of this journal and the author's affiliated institutions.

\title{
Drugs Abuse, Law, and Society: The Role of Penitentiary Institution
}

\author{
Wahyullah A YUSUF( \\ Faculty of Law, Universitas Musamus \\ Jl. Kamizaun Mopah Lama, Rimba Jaya, Kec. Merauke, \\ Kabupaten Merauke, Papua 99611, INDONESIA \\ 凶wahyullahayusuf@gmail.com
}

\begin{abstract}
The problem of criminal narcotics crime has become the problem of nations and nations in the world that is always talked about. Around the world the problem of narcotics abuse is almost all the problems of nations. Narcotics abuse can certainly lead to physical damage, mental health, emotions, and attitudes in society. Problems of narcotics abuse have been threatening society and nation to become an organized crime in the national scope as well as to the international world. This study aims to analyze the problem of how the application of criminal law regarding the regulation of narcotics crime in Indonesia and how the criminal law system concerning the regulation of narcotics crime in Indonesia. Research
\end{abstract}


method in scientific journal is done by normative juridical approach that is by doing analysis of problem through approach of law principles and referring to legal norms contained in legislation. The data used in this scientific journal is secondary data. This study found and emphasized that penitentiary institution has an important and strategic role on rehabilitating the drug abuse actors. However, in some cases, the penitentiary

KEYWORDS. Narcotics crime; Drug users; Penitentiary Institution; Rehabilitation; Society

\section{INTRODUCTION}

Many crimes committed by the community to meet the needs of his life. One of the criminal acts committed by society to fulfil the necessities of life is the crime of narcotics. Currently, narcotics crimes often occur in Indonesia, whether committed by Indonesian citizens themselves and foreign nationals who conduct drug transactions in Indonesia. Indonesia is now one of the safest places for criminals to transact drugs.

The problem of drug abuse in Indonesia in recent years has become a serious problem and has reached a state of concern. Even the problem of drugs is not only a national issue, but regional as well as international. The threat of drug abuse and trafficking is so alarming, it is marked by high rates of drug abuse from year to year. The number of drug abuse from year to year has increased, in 2017 the number of drug users in Indonesia reached 5.8 million people. This is because the number of drug users to date has reached 4 million people.

In the field of law, in 1997 the government issued 2 (two) laws regulating the drug, namely Law No. 5 of 1997 on Psychotropic and Law No. 22 of 1997 on Narcotics. Both laws provide a serious threat of punishment for both producers, distributors, and users. The birth of the 
two laws, there is criminalization of drug abuse. The criminal provisions in the Psychotropic Law are regulated in Articles 59 to 64, while the Narcotics Law is regulated in Articles 78 to 99. The grouping of crimes in the Narcotics and Psychotropic Act is essentially no different, such as crimes involving production, distribution, use, and other crimes such as drug and rehabilitation, labelling and advertising, transit, criminal reporting, and destruction. Although both laws have regulated sanctions for drug abuse, several previous studies have shown that drug abuse is influenced by several things, ranging from family, economy, education, to the prison system which in many studies is said to be ineffective for drug abusers (Arimuladi, Utama, \& Asmara, 2021; Saefudin, 2020; Monalisa, Rahayu, \& Wahyudhi, 2020). In fact, several other studies show the weakness of the application of criminal sanctions in Indonesia for drug abusers when compared to similar sanctions in the same case in several countries (Warsiono, Supanto, \& Novianto, 2020; Hidayat, 2018; Pasaribu, 2018; Widiasyam, Haris, \& Abdullah, 2020).

Guidance on the victims of drug abuse requires special treatment, since usually the victims of drug abuse is a distributor or user so that in the process of coaching will occur the process of removing things that have been owned or habits that often do. Such special behavior is intended to eliminate and stop the desire to use narcotics and replace it with other constructive behavior (Panjaitan \& Simorangkir, 2017).

Therefore, this study will anaylze two main point, first concerning how is the prisoners' guidance on drug users in Penitentiary, and second what factors are inhibiting and supporting the Penitentiary in conducting guidance of prisoners on drug users. The objectives of this study are to know the effort of fostering the prisoner on the drug user in Correctional Institution, and to know the factors inhibiting and supporting the Institute Penitentiary in conducting guidance of prisoners on drug users.

In order to unify perception in interpreting the purpose and purpose of this study, the authors describe the operational definition of research as follows: 
1) Correctional institutions are places where people have a criminal offense because the judge's decision has had permanent legal force.

2) Coaching is an effort made by a person or group of people in order to maintain, care for, build something to be better, higher in value and better condition than before experiencing the process of coaching.

3) Inmates are a prisoner based on a criminal court decision by eliminating their independence in the community. In this case the inmates in question are inmates of narcotics abuse either distributors, suppliers, or users.

4) Drug or drug is a substance that when entered into the body will affect the body of a person, especially the central nervous system / brain so that if misused will cause physical, psychological, and social function.

\section{DRUG ABUSE: ITS LEGAL DEVELOPMENT AND SOCIETY RESPONSE}

Drugs are chemicals that can change the state of psychology such as feelings, thoughts, moods, and behavior, if entered the human body either by eating, drinking, inhaled, intravenous, intravenous, and so forth. Drugs are divided into three types as follows Narcotics, Psychotropic, and other addictive substances (Syafii, 2009).

The term narcotics is known in Indonesia derived from the English "Narcotics" which means drugs, which is synonymous with the word "Narcosis" in Greek which means to stifle or to discriminate. But basically, narcotics itself is a kind of plants that have flowers that can anesthetize people become unconscious in the sense of anesthetized and do not feel anything. According to Law No. 35 of 2009 Article 1, narcotics are substances or drugs derived from plants or non-plants, both synthesis and semisynthetic that can cause decreased or altered consciousness, loss of taste, reduce, to relieve pain, and can cause dependence, distinguished into 
groups as attached to the Act. Narcotics classification as stipulated in Article 6 of Law No. 35 of 2009, is as follows:

1) Narcotics Group I is a Narcotics that can only be used for scientific development purposes and not used in therapy and has a very high potential to cause dependence.

2) Narcotics Group II is a medicinal narcotic used as a last resort and can be used in therapy and / or for scientific development purposes and has high potential to cause dependence.

3) Narcotics Group III is a medicinal Narcotic treatment and widely used in therapy and / or for the purpose of science development and has the potential to cause mild dependence. At first Narcotics substances found people whose use is intended for the benefit of mankind, especially in the field of medicine. With the rapid development of the pharmaceutical industry today, the category of Narcotic substances is widespread as well as those contained in the attachment of the Narcotics Act No. 22 of 1997.

Thus, for a relatively long period of time the wearer may require treatment, supervision, and control to be cured. Based on the decision of Minister of Health of the Republic of Indonesia No. 2882/70, Narcotics or narcotics that can be interpreted as materials that generally have a working effect that is:

1) Unleash (can decrease awareness)

2) Stimulate (improve work performance)

3) Charge (bind / dependence)

4) Fantasy (hallucinations), physical or psychological victims

Abuse is using power and so it is not as it should be. By abusing something, be it power, things, etc., someone wants to get something they think can benefit them. Drug abuse committed by a person can be interpreted to use drugs is not as it should be, in this case certainly outside the supervision of a doctor. Forms of drug abuse as emphasized by Wienahyu (2012) are as follows: 
a. Drugs if used proportionally, meaning according to the principle of utilization, both for health and for the benefit of science, then it cannot be categorized as a narcotic crime. However, if it is used for other purposes, the act can be categorized as a clear act as a criminal act and /or substance abuse based on Law No. 35 of 2009 (Republic of Indonesia, Art. 6, Law 35/2009).

b. Commonly known forms of drug crime include:

1) Abuse/overdose

2) Drug distribution; because of its attachment to a chain of narcotics circulation, both nationally and internationally.

3) Sale and purchase of drugs; this is generally motivated by the motivation to seek material advantage, but there is also because of motivation for satisfaction.

Of the three forms of narcotics crime, it is one of the causes of various forms of criminal acts of wickedness and offense, which directly resulted in the demoralization of society, the younger generation, and especially for the users of the harmful substances themselves, such as: killing, mugging, extortion, rape, fraud, traffic beacon infringement, harassment of security forces, and so on (Hamzah, 2013).

One of the fundamental reasons for the prohibition of drugs is due to the negative effects it has on health. Not only the disease that is directly caused by the consumption of drugs, but also deadly aftershocks due to illegal drug administration performed unfit, such as HIV/AIDS, hepatitis, and bronchitis. Disorders and psychological illnesses caused by drugs are influenced by two things, namely the mental state of the individual before becoming a drug user and the experience of an individual since the victim first took the drug. In general, drug abuse can be divided into three major groups as stated by Tavip (2009), namely:

1) Primary Dependency Characterized by anxiety and depression that are generally present in people with unstable personalities. These people can actually be classified as a sick person, but one gets lost to drugs in 
an attempt to self-medicate that should seek the help of a doctor (psychiatrist). This category requires therapy and rehabilitation rather than punishment.

2) Reactive Dependency Usually there are in adolescents because of the curious urge, persuasion and seduction of friends, pitfalls, and the pressure and influence of peer group friends. These people are victims, these groups require therapy and rehabilitation rather than punishment.

3) Systematic Dependency Drug abuse as one of the symptoms of antisocial personality type (psychopath) and drug use is for pleasure only. These people can be classified as criminals because they often also serve as dealers. They are in addition to requiring therapy and rehabilitation as well as punishment.

\section{DRUG ABUSE AND PENITENTIARY INSTITUTION: LAW AND SOCIETY APPROACH}

A prisoner is a person who is serving a jail term. The term inmates for those who were sentenced implicated the loss of independence to move. During the loss of freedom of movement, inmates should be introduced to society and should not be alienated from it. It is intended that if they are serving the punishment, they also formed their mental readiness to return to life in the community normally without repeat the mistake. A prison sentence is defined as a crime for deprivation or deprivation, or limitation of a person's freedom to determine the will (psychic) in doing something for a certain period resulting from the judge's decision (Gunakarya, 2015).

In its history, the imprisonment is known as a public reaction due to a crime committed by a violator of the law. Therefore, imprisonment is also referred to as the criminal disappearance of independence, in which a person is social exiled from the original environment. The nature of prison criminal reform is not to remove the type of imprisonment, but to point to 
the preparation of new attempts to imprisonment to avoid the bad influence of the iron wall, and the treatment of new ways of prisoners that are more in line with the universally accepted spirit of human rights.

Narcotics crime can be interpreted with an act that violates the provisions of narcotic law, in this case is the Law No. 35 of 2009 on Narcotics and other provisions which are inconsistent and not contrary to the Act (Poernomo, 2015).

\section{CORRECTIONAL INSTITUTIONS, PRISONERS' GUIDANCE, PRINCIPLES AND COACHING PURPOSES: PROBLEMS AND CHALLENGES IN LAW AND SOCIETY APPROACH}

Referring to the opinion of Kosnoen, the term prison comes from the Java language "penjoro", which means repentance. While Bahroedin Soejobroto called the prison word comes from the word "penjera". Both understandings imply prison as a punitive place to make a deterrent and instill fear of society so as not to oppose the fear of society not to oppose colonial Dutch colonists. The substitution of prison into "Penal Institution" has good intentions, that is, the giving and shelter of the targeted citizens not only focuses on the funitative intend but is oriented towards more humane acts and adapted to the conditions of the targeted citizens. Although the term pemasyarakatan already appeared on July 05, 1963, but the principles of pemasyarakatan was only institutionalized after the development of the Conference of Directorate of Corrections Penitentiary. The result can be concluded that the purpose of prison sentence is not only to protect the people solely, but also to try to foster the violator of law, where the violator is no longer referred to as a criminal, in hopes to take the maximum benefit from the system of understanding applied to him (Emqi, 2014). 
Penitentiary declared as a system of guidance against the violators of law and as a justice that aims to achieve social reintegration or recovering the unity of relations between prisoners and community built. According to Law no. 12 of 1995 regulated on Correctional Article (12) paragraph (1) which reads: "In the framework of guidance on prisoners in Penitentiary classification done on the basis of: $a$. Age; $b$. Gender; $c$. Criminal time was dropped; d. Type of crime; e. Other criteria that match the needs or development of coaching".

The Penitentiary is headed by a Head of Penitentiary. In carrying out its duties, this institution consists of parts that have the duty and authority of each. The parts are still divided into sub-section or sub section that aims to realize the effectiveness of work.

A right is in fact an authority to do good or not to do, while obligation is a burden or a task to be performed. Roles can be spelled out into the following elements:

1) Ideal role (ideal role)

2) The role that should (expected role)

3) Roles considered by the self (perceived role)

4) The actual role performed (actual role)

\section{CONCLUSION}

Drug abuse has involved many elements. The narcotics cartels play a role in the high circulation of narcotics in Indonesia. Officials, pilots, law enforcement officers, students to children have been the victims of drug abuse. Law enforcement officers even work with narcotics cartels to sell and keep the narcotics cartels. Law enforcement that can be bribed and very weak, the added element that causes abuse of narcotics remain high in Indonesia. The concept of criminal law for narcotics itself includes criminal acts, criminal and non-penal law (penal). Criminal action is a science of crime prevention that can be done by combining the application of criminal and preventive facilities without the use of criminal means. 
Criminal law action is an effort to overcome crime by using criminal means. While related to non-criminal action is a precautionary measure before the occurrence of a crime. Criminal acts against the arrangement of narcotics crimes in Indonesia include criminal liability, acts that are qualified as criminal offenses and criminal sanctions. The criminal responsibility itself consists of accountability committed by humans and corporations as subjects of criminal offenses. Prohibited acts consist of passing narcotics or narcotics precursors and misusing narcotics or narcotics precursors for both yourself and others.

In the application of Law No. 35 of 2009 concerning Narcotics to be more effective it is necessary to have coordinated actions between the parties or agencies such as between the police and the National Narcotics Board, the Ministry of Transportation, the Ministry of Education and Culture, the Ministry of Religious Affairs, educational institutions, community organizations and others, other. To prevent narcotic crime, it is necessary to intensify counselling about the dangers of narcotics through mass media such as newspapers, magazines, internet, social networking (Facebook, twitter) etc., so that community members are aware of the great dangers of narcotics, so that every family can make internal family prevention efforts. Family defence is the most important effort in preventing the circulation and abuse of narcotics. Law enforcement officials have not cooperated with narcotics cartels and refused all compromises. Law enforcement officials must also have high morals, so as not to become victims of abuse of narcotics itself. It is dangerous and worrying if law enforcement officers should enforce the law but use the narcotics themselves.

\section{REFERENCES}

Arimuladi, S. U., Utama, Y. J., \& Asmara, T. (2021). Protection of Human Rights for Narcotics Users: A Critique of the Use of Criminal 
Sanctions in Efforts to Eradicate the Spread of Narcotics in Indonesia. Journal of Drug and Alcohol Research, 10(7), 23-31.

Emqi, M. F. (2014). Model Pembelajaran Pendidikan Agama Islam dalam Pembinaan Mental Narapidana (Studi Multikasus di Lembaga Pemasyarakatan Kelas I Malang dan Lembaga Pemasyarakatan Wanita Kelas II A Malang). J-PAI: Jurnal Pendidikan Agama Islam, 1(1), 49-65. https://doi.org/10.18860/jpai.v1i1.3359

Gunakarya, A. W. (2015). SA, Sejarah dan Konsepsi Pemasyarakatan. Bandung: CV. Armico.

Hamzah, A. (2013). Kejahatan Narkotika dan Psikotropika. Jakarta: Sinar Grafika.

Hidayat, M. (2018). Juridical Review of Decriminalization on Efforts to Cut Drugs Users' Addiction in Indonesia. YURISDIKSI: Jurnal Wacana Hukum dan Sains, 11(2), 1-12.

Monalisa, M., Rahayu, S., \& Wahyudhi, D. (2020). A Comparative Study on Criminal Sanction Against Drugs Offenders. Jambe Law Journal, 2(2), 181-206.

Panjaitan, P. I., \& Simorangkir, P. (2017). Lembaga Pemasyarakatan dalam Perspektif Sistem Peradilan Pidana. Jakarta: Midas Sura Grafindo.

Pasaribu, R. (2018). Fight Narcotics with Community Strengthening: Crime Control Management by Community Policing. JILS (Journal of Indonesian Legal Studies), 3(2), 237-252.

Poernomo, B. (2015). Pelaksanaan Pidana Penjara dengan Sistem Pemasyarakatan. Yogyakarta: Liberty.

Republic of Indonesia. (1995). Undang-Undang Nomor 12 Tahun 1995 Tentang Pemasyarakatan.

Republic of Indonesia. (2009). Undang-Undang Republik Indonesia Nomor 35 Tahun 2009 Tentang Narkotika.

Saefudin, Y. (2020). Rehabilitation Policy for Drugs Abuse in Indonesia. Indian Journal of Forensic Medicine \& Toxicology, 14(4).

Syafii, A. (2019). Penyalahgunaan Narkoba dalam Perspektif Hukum Positif dan Hukum Islam. HUNAFA: Jurnal Studia Islamika, 6(2), 
219-232. https://doi.org/https://doi.org/10.24239/jsi.v6i2.135.219232

Tavip, M. (2009). Pelaksanaan Therapeutic Community dan Rehabilitasi Terpadu Bagi Narapidana Narkotika dan Psikotropika di Lembaga Pemasyarakatan Klas I Medan Dihubungkan dengan Tujuan Sistem Pemasyarakatan. Thesis. Medan: Universitas Sumatra Utara. Warsino, W., Supanto, S., \& Novianto, W. T. (2020). Forensic Examination and Restorative Justice for Drug Abusers: An Alternative in Handling Drug Cases in Indonesia. Indian Journal of Forensic Medicine \& Toxicology, 14(2).

Widiasyam, S., Haris, O., \& Abdullah, S. A. (2020). Criminal Law Study on Narcotics Abuse Rehabilitation. IJCLS (Indonesian Journal of Criminal Law Studies), 5(1), 55-62.

Wienahyu, R. S. (2012). Penerapan Tindak Pidana Narkotika Terhadap Pengguna Tinjauan Yuridis Terhadap Pengadilan Negeri Purwekerto Nomor: 68/Pid.Sus/2011/PN.Pwt. Thesis. Purwokerto: Universitas Jenderal Soedirman.

\section{Conflicting Interest Statement}

All authors declared that there is no potential conflict of interest on publishing this article.

\section{Funding}

None

\section{Publishing Ethical and Originality Statement}

All authors declared that this work is original and has never been published in any form and in any media, nor is it under consideration for publication in any journal, and all sources cited in this work refer to the basic standards of scientific citation. 